\title{
Ayurvedic Management of Avaranjanya Madhumeha WSR Type 2 Diabetes Mellitus-A Case Report
}

\section{Hardik CY, Chhimpa R, Yadav CR and Dadhich OP* \\ PG Department of Sharir Kriya, NIA, Jaipur, India}

*Corresponding author: Om Prakash Dadhich, PG Department of Sharir Kriya, NIA, Jaipur, India, Email: Chudasamahardik1991@gmail.com

\section{Case Report}

Volume 2 Issue 9

Received Date: November 24, 2018

Published Date: December 19, 2018

DOI: $10.23880 /$ jonam- 16000161

\section{Abstract}

Diabetes mellitus (DM) commonly referred to as diabetes. It is a group of metabolic disorders in which there are high blood sugar levels over long period of time. Its symptoms include frequent urination, increased thirst and increased hunger. Proper medication is not provided in period of time, than it may cause many complications. Acute complications can include diabetic ketoacidosis, hyper osmolarity and hyperglycemic state. Serious long term complications include foot ulcers, blindness, chronic kidney disease, cardiovascular disease and stroke may leads to death. In Ayurveda it can co-related with Avaranajanya Madhumeha characterized by madhuryamasyata, karapadadaha, sweda-angagandha, shithila-angata etc. A 35 year old male patient reported to the outdoor department of Sharir Kriya NIA, Jaipur, with the complained of shithilangata, kriya-hani, klam, mootraadhikta, kara-paad tale daah for more than 2 to 3 months. The patient was diagnosed as Madhumeha. Regular fifteen days visit was done in the form of follow up for 2 months. After 2 months of treatment significant responses were found.

Keywords: Prameha; Type 2 Diabetes Mellitus; Shaman Aushadhis

\section{हिन्दी सारांश}

\section{आवरणजन्य मधुमेह व्याधि में आयुर्वेद चिकित्सा}

डॉ. चुडासमा हार्दिक, डॉ. राकेश छिम्पा, डॉ. यादव सी. आर., प्रो. ओ.प्र.दाधीच

मधुमेह सामान्यतः प्रमेह व्याधि के स्वरुप में जाना जाता है, यह एक चयापचय जन्य विकारों का समूह है जिसमे की रक्त में शर्करा की मात्रा अधिक समय तक बढी रहती है। उनके लक्षणों में बार बार मूत्र प्रवृति होना, भूख एवं प्यास की मात्रा में वृद्धि होना सामान्य रूप से माना जाता है, जो की सही समय पर उचित चिकित्सा नहीं दी जाए तो वो काफी सारे उपद्रव पैदा कर सकती है। नवीन उपद्रवो में डायबिटीस
कीटोअसिडोसिस, हाइपर ओसमोलर एवं हाइपर ग्लैसेमिक अवस्था या मृत्यु जीर्ण उपद्रवो में हृद वाहिनी विकार, हृदयघात, जीर्ण वृक्क विकार, डायबेटिक फूट अलसर और आखों पर दुष्प्रभाव । आयुर्वेद में इस की तुलना प्रमेह के साथ की जा सकती है इनके लक्षणों में मधुरास्यता, कर-पाद दाह, स्वेदो अंग गंधता, शिथिल अंगता इत्यादि । प्रस्तुत शोध में एक पुरुष जिनकी उम्र ३५ वर्ष, निरंतर २- ३ माह से शिथिलान्गता, क्रियाहानि, क्लम, मूत्राधिक्य, हस्त-पाद तल दाह आदि समस्याओं से परेशान थी। आयुर्वेद सिद्धांतो के अनुसार निदान आवरणजन्य मधुमेह निश्चित किया गया। नियमित १५ दिन के अन्तराल पर बहिरंग विभाग में $२$ माह के चिकित्सीय परामर्श के बाद उपरोक्त लक्षणों में अच्छा लाभ प्राप्त हुआ। 


\section{Journal of Natural \& Ayurvedic Medicine}

\section{Introduction}

Diabetes mellitus is a clinical syndrome characterized by hyperglycemia due to absolute or relative deficiency of insulin. This can arise in many different ways but it is most commonly due to autoimmune type 1 diabetes or to adult onset type 2 diabetes [1]. In the year 2000, 171 million people had diabetes, and this is expected to double by 2030 . This is globally pandemic principally involves type 2 diabetes, to which several factors contribute, including grater longevity, obesity, unsatisfactory diet, sedentary lifestyle and increasing urbanization. Many case of type 2 diabetes remain undetected. However the prevalence of both type of diabetes varies considerably around the world, and is related to differences in genetic and environmental factors.

According to Ayurveda it is co-related with the disease Prameha which manifests in the form of madhuryamasyata, karapadadaha, sweda-angagandha, shithila-angata etc [2]. Madhumeha arises in two ways, by the aggravation of vata caused by a) dhatuksayadepletion/loss of tissues and b) obstruction of its path (movement) by the doshas covering it. In the obstructed kind, it (vata) exhibits the symptoms of the dosha covering it, without any other reason, occasionally, hence the bladder is found sometimes empty and sometimes full, and the diseases becomes difficult to cure. All varieties (of prameha) if neglected will, in course of time, become madhumeha. The line of the treatment of diabetes is-dietary and life style modification, oral-anti diabetic agent and insulin by injection [3].

Looking in to these limitations in the treatment and prognosis of Diabetes mellitus type 2, a single case of Prameha generally obese patient should be treated with purification therapy and those who are not suitable for purification should be treated with saman (therapy to mitigate the dosha). So, here patient was observed by using Deepan Pachan (Digestive-Carminative), Strotas shodhak (Rasa, Meda and Mutravaha strotas) and Ruksha, Ushna, Tikshna dravyas to analyze its effect in the management of the disease [4].

\section{Aims and Objectives}

To estimate the efficacy of Ayurveda drug in management of Avaranajanya Madhumeha W.S.R. Type 2 Diabetes mellitus.

\section{Material and Methods}

\section{Types of Study}

Single observational case without any control group.

\section{Study center}

National Institute of Ayurveda Hospital, Jaipur (Rajasthan).

\section{Study details}

A Hindu, married 35 year old male patient visited (November 13, 2017) the outdoor department of Sharir Kriya of NIA, Jaipur with OPD no 8213112017 for the chief complains of madhuryamasyata (Sweet taste of mouth), karapadadaha (Burning sensation at sole), sweda-angagandha (Excessive Perspiration), shithilangata (Debility), kriya-hani (Uneasiness), mootraadhikta (polyurea) for more than 2 to 3 month, and other associated complains were Kshudha Vriddhi (Excessive hunger) Nindra vriddhi (Excessive sleep), Vibandha (constipation) for last 1 month.

Personal history revealed that the patient is vegetarian and used to take extra oily and fatty diet, with regular habit of intake of Homemade food, Excessive sleep, frequency of micturation 12-14 times/day and patient has no addiction. The patient has constipation and urge of defecation in once / 2 day. Past history-Patient was suffering from type 2 Diabetes mellitus for more than 1 and half years. But he was very much irregular in taking medicines and routine checkup of Blood sugar Level. Drug History: Patient was on metformin in other system of medicine such as allopath system. Family history-There is no any significant family history.

The General examinations of the patient showed dryness of tongue and vitals were; pulse rate $84 / \mathrm{min}$, respiratory rate of $18 / \mathrm{min}$, blood pressure of $120 / 70 \mathrm{~mm}$ of $\mathrm{Hg}$ and body weight is $80 \mathrm{~kg}$. Per abdominal examination showed fullness of abdomen and tenderness in Right hypochondriac region, epigastric and umbilical region. The impression of Blood Sugar Level and Urine analysis on November 13, 2017 implies Fasting Blood sugar level $283 \mathrm{mg} / \mathrm{dl}$ (65-110 mg/dl Normal), Post prandial Blood Sugar level $483 \mathrm{mg} / \mathrm{dl}(90-140 \mathrm{mg} / \mathrm{dl}$ Normal), In Urine- Appearance Dark yellow, PH 5.0, Specific gravity 1.030, Sugar 3+, Protein 2+, Epithelia cell 1-2, WBC 0-1 RBC and Crystals are Nill. Based on clinical presentation, Patient was diagnosed as a case of Prameha. 


\section{Journal of Natural \& Ayurvedic Medicine}

\section{Treatment Plan}

The Following oral medicines were administrated for 3 month.

- A combination in powder form of Madhumehari (5g) and Prameha prahar (2g) twice a day with Luke warm water before Meal.

- Arjuna twak Churna (5g) twice a day with Luke warm water after Meal.

- Tab Basant Kusumakar Rasa (2 tab) are administrated with Luke warm water twice a day after meal.

- Tab Shiva Gutika (1 Tab) And Chandraprabha Vati (2 tab) twice a day with Luke warm water are administrated after Meal.

- Triphala Churna (5g) is administrated orally at night with Luke warm water.

On the first follow up (after 15 days of the treatment) patient reported reduction in previous mentioned symptoms. Improvement was noted in weakness, sleep, and appetite and bowel habit. On the second follow up digestion power of patient was improved. On the third follow up appetite of Patient was improved and patient feel lightness and energetic in routine activity on the fourth follow up. At that time of every visit he again advised to investigate Blood Sugar Level and Urine analysis.

The patient was on follow up till $2^{\text {nd }}$ month without any single episode of replace. In this case study, assessment was done on the basis of sign and symptoms as well as of Blood Sugar Level and Urine analysis. After $2^{\text {nd }}$ month of drug intervention Fasting Blood sugar level $283 \mathrm{mg} / \mathrm{dl}$ reduce to $108.0 \mathrm{mg} / \mathrm{dl}$, Post parandial Blood Sugar level $483 \mathrm{mg} / \mathrm{dl}$ reduced to $179.0 \mathrm{mg} / \mathrm{dl}$. In UrineAppearance Dark yellow changed to Pale yellow, PH 5.0, reduced to 6.0 , Specific gravity 1.030 reduced to 1.015 Sugar $3+$ reduced to Nill, Protein $2+$ reduced to Nill after 2 month. This indicates that after orally medication and restriction of the food relief was noted (Tables 1-4).

\begin{tabular}{|c|c|c|c|}
\hline Sr. no & Follow Up (Time of Period) & Fasting Blood Sugar (FBS) & Post prandial Blood Sugar (PP2BS) \\
\hline 1 & $1^{\text {st }}$ Visit $13 / 11 / 2017$ & $283 \mathrm{mg} / \mathrm{dl}$ & $483 \mathrm{mg} / \mathrm{dl}$ \\
\hline 2 & $2^{\text {nd }}$ Visit $30 / 11 / 2017$ & $107 \mathrm{mg} / \mathrm{dl}$ & $192 \mathrm{mg} / \mathrm{dl}$ \\
\hline 3 & $3^{\text {rd }}$ Visit $18 / 12 / 2017$ & $138 \mathrm{mg} / \mathrm{dl}$ & $184 \mathrm{mg} / \mathrm{dl}$ \\
\hline 4 & $4^{\text {th }}$ Visit $31 / 12 / 2017$ & $108 \mathrm{mg} / \mathrm{dl}$ & $179 \mathrm{mg} / \mathrm{dl}$ \\
\hline
\end{tabular}

Table 1: Assessment of Blood Sugar Level (God-Pod Method).

\begin{tabular}{|c|c|c|c|c|c|c|c|}
\hline Sr. no & Follow Up & Appearance & Color & Reaction(Ph) & Albumin & Sugar & Specific Gravity \\
\hline 1 & $1^{\text {st }}$ Visit 13/11/2017 & Clear & Dark Yellow & 5.0 & $2+$ & $3+$ & 1.030 \\
\hline 2 & $2^{\text {nd }}$ Visit 30/11/2017 & Clear & Pale Yellow & 6.0 & Nill & Nill & QNS \\
\hline 3 & $3^{\text {rd }}$ Visit 18/12/2017 & Clear & Dark Yellow & 5.5 & $1+$ & Trace & 1.030 \\
\hline 4 & $4^{\text {th }}$ Visit 31/12/2017 & Clear & Pale Yellow & 6.0 & Nill & Nill & 1.015 \\
\hline
\end{tabular}

Table 2: Assessment of Urine Analysis.

\section{Observation and Result}

\begin{tabular}{|c|c|c|c|}
\hline Sr. No & Characteriscs Features & Before Treatment & After Treatment \\
\hline 1 & Madhurasyata & 3 & 2 \\
\hline 2 & Karapada daha & 3 & 1 \\
\hline 3 & Sweda angagandha & 3 & 1 \\
\hline 4 & Shithila-angata & 3 & 1 \\
\hline 5 & Ati Shyya- Asana & 3 & 1 \\
\hline 6 & Ati swapna sukhata & 3 & 1 \\
\hline 7 & Gala talu sosha & 3 & 1 \\
\hline 8 & Hrud-Netra-Jihva-Upadeha & 3 & \\
\hline
\end{tabular}

Table 3: Assessment of Classical Sign \& Symptoms. 


\section{Journal of Natural \& Ayurvedic Medicine}

\begin{tabular}{|l|c|l|}
\hline 1 & Cure & 0 \\
\hline 2 & Better & 1 \\
\hline 3 & Moderate relief & 2 \\
\hline 4 & Mild relief & 3 \\
\hline
\end{tabular}

Table 4: Grading Suggests.

\section{Discussion}

1. Madhumeha is Kapha Vata pradhan Tridoshaj vyadhi. It has two types as per vagbhatta Dhatu Kshayaj Madhumeha (type 1 Diabetes Mellitus) Avaranajanya Madhumeha (type 2 Diabetes Mellitus) [5].

2. Patient being diagnosed as Avaranjanya Madhumeha, drugs acting upon main component of pathology like meda dhatu, Kleda, Kapha and Meda Dhatvagni as well as having Deepan, Pachan, Lekhan and Avaranhar properties were selected to assess its efficacy on Avaranjanya madhumeha.

3. The drugs which have Deepan- pachan properties like Chitrak, Musta, Sunthi, Bilva, Shatpushpa etc [6]. Lekhan properties like Musta, Chitrak, Vansha, Dalchini, Madhu, Methika, Shilajatu, Pushkarmool, Rasna etc [7]. Avaranhar Properties like- Haritaki, Sonamukhi, Kankol, Methika [8].

4. Probable pharmacological activities and probable mode of action of the drug is mentioned below (Table 5) (Figures $1 \& 2$ ).

\begin{tabular}{|c|c|c|}
\hline S.No & Drugs & Reported Activity \\
\hline 1 & Madhumehari Churna [9] & Immunomodulatory, Antihyperglycemic \\
\hline 2 & Prameha Prahar Churna & Hypolipidaemic, Antidiabetic \\
\hline 3 & Arjuna tvak churna [10] & Cardiac tonic, Hepatoprotective, Hypoglycemic \\
\hline 4 & Vasant Kusumakar rasa [11] & Antioxidant, Immunomodulator, Antihyperglycemic \\
\hline 5 & Shiva gutika [12] & Antioxidant, Antidiabetic \\
\hline 6 & Chandra prabhavati [13] & Antidiabetic, Antioxidant \\
\hline 7 & Triphala Churna [14] & \\
\hline
\end{tabular}

Table 5: Reported Pharmacological Activities of Drugs.

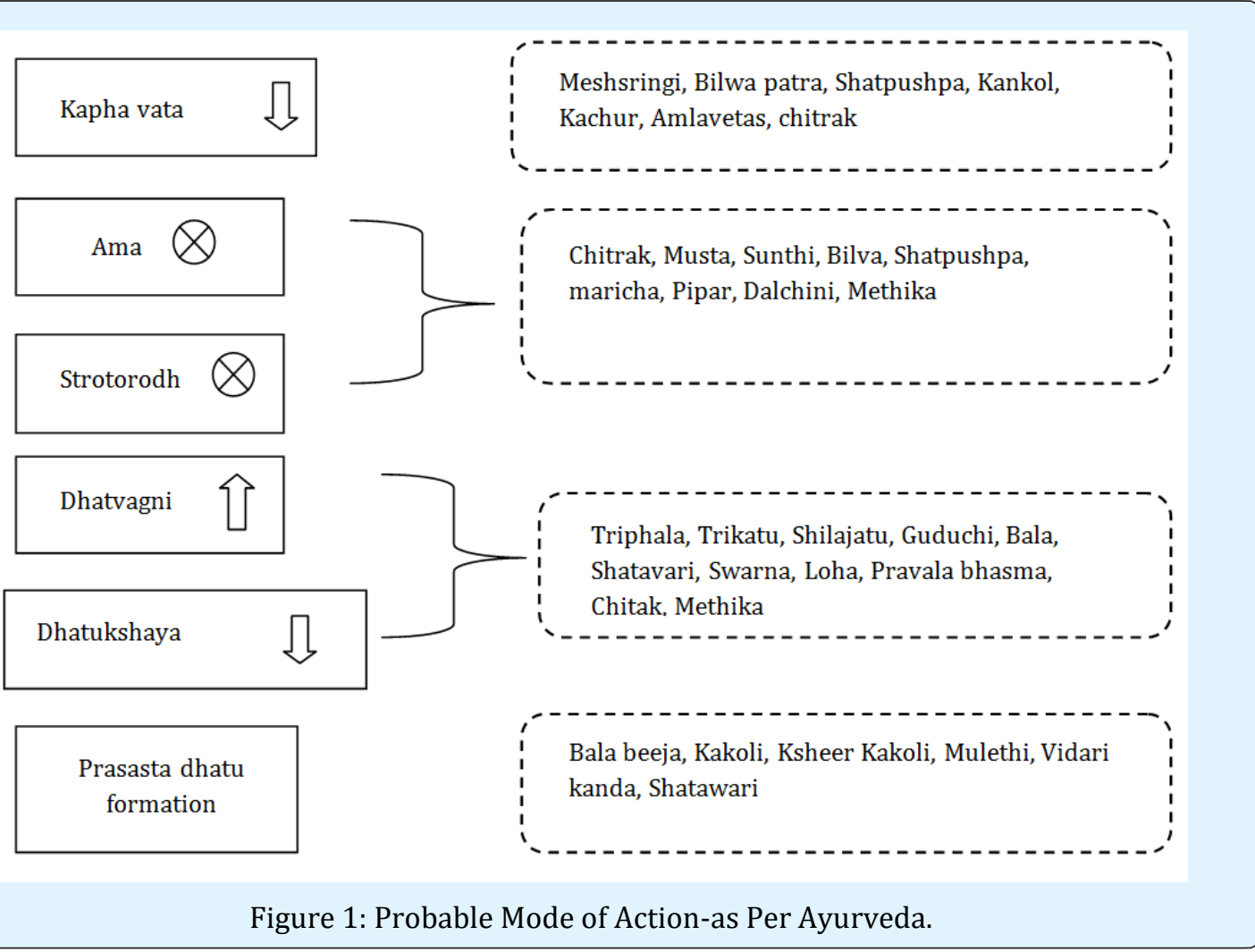

Dadhich OP, et al. Ayurvedic Management of Avaranjanya Madhumeha WSR Type 


\section{Journal of Natural \& Ayurvedic Medicine}

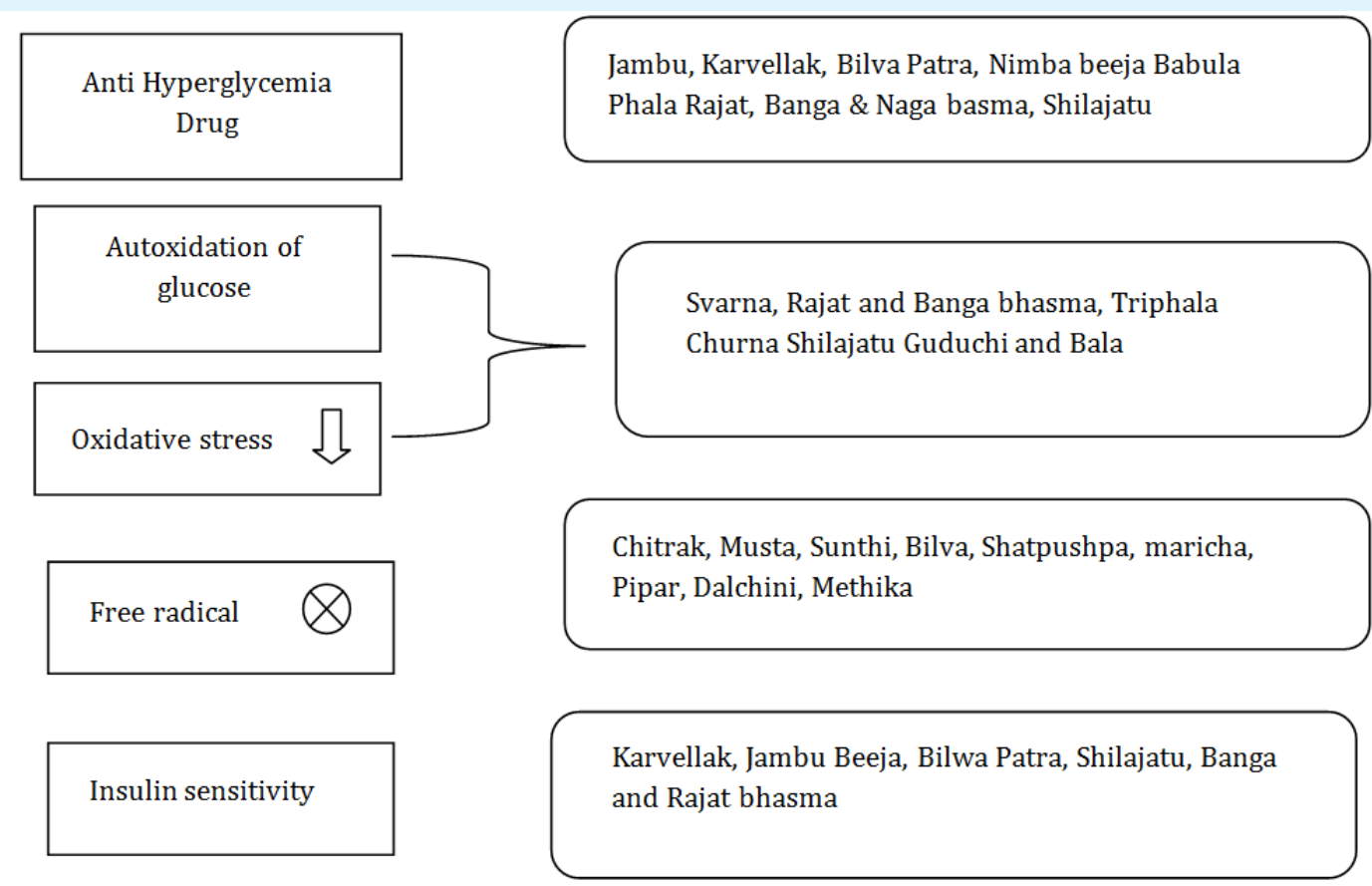

Figure 2: Probable Mode of Action-as Per Modern.

\section{Conclusion}

In this study it's proved that Deepan-Pachan, hepato protective, Strotas shodhak (Rasa, Meda and Mutravaha strotas) and Ruksha, Ushna, Tikshna dravyas corrects the digestion and improve the metabolism. If a person follows the proper routine along with these medicines it might be safe and effective for such cases (Diabetes mellitus type 2) [15].

\section{References}

1. Davidson's principles \& practice of Medicine, Edition 20, Elsevier publication, Chapter 21 Diabetes mellitus, pp: 808.

2. Acharya TY (2007) Agnivesh; Caraka Samhita, Ayurveda Depika Commentry by Sri Chakrapanidutta, Chaukhamba Prakashan , Varanasi, Nidansthana 4/47, pp: 215.

3. Boon NA, Colledge NR, Walker BR (2018) Davidson's principles \& practice of Medicine, Edition 20, Elsevier publication, Chapter 21 Diabetes mellitus, pp: 818.

4. Acharya TY (2007) Agnivesh; Caraka Samhita, Ayurveda Depika Commentry by Sri Chakrapanidutta,
Chaukhamba Prakashan, Varanasi, Chikitsasthana 6/15-17, pp: 446.

5. Paradakara HSS (2016) Vagbhat, Ashtanga Hridaya A, Sarvangasudara and Ayurveda Rasayan Commentary of Arundutta and Hemadri, Bhisagacharya, Chaukhamba Surbharati Prakashan, Varanasi, Nidansthana Chapter 10/18, pp: 504.

6. Tripathi B (2013) Shadangadhar Samhita, containing Anjannidana of Maharshi Agnivesh, a noted with Dipika hindi commentary, Chaukhamba Surbharati Prakashan, Varanasi, Purvakhanda, Chapter 4/1, pp: 33.

7. Tripathi B (2013) Shadangadhar Samhita, containing Anjannidana of Maharshi Agnivesh, a noted with Dipika hindi commentary, Chaukhamba Surbharati Prakashan, Varanasi, Purvakhanda, Chapter 4/10, pp: 34.

8. Acharya TY (2007) Agnivesh; Caraka Samhita, Ayurveda Depika Commentry by Sri Chakrapanidutta, Chaukhamba Prakashan, Varanasi, Chikitsasthana 28/217-218, pp: 626. 


\section{Journal of Natural \& Ayurvedic Medicine}

9. Tank B, Sharma CB, Saroj UR (2017) Clinical Evaluation of Efficacy of Madhumehari Churna with Different Kwatha in the Management of Madhumeha WSR to Diabetes mellitus Type II (NIDDM)" dissertation was submitted on April 2017 at National Institute of Ayurveda Jaipur.

10. Sharma PV (2013) Dravya Guna Vijananam, Vegetables druges, Chaukhamba Bharati Academy, Varanasi. Hridayadi varga, chapter 3, pp: 195.

11. Shah NC (2012) Bharat Bhaishjya Ratnakar, BK Jain Publishers, Shlok no- 6167.

12. Siddhinandan Mishra (2015) Bhaishajya Ratnavali of Kaviraj Govind Das Sen, Edited with 'Siddhiprada' Hindi Commentory. Choukhamba Surbharati Prakashan, Varanasi, Rasayanaadhikar chapter 73, Shlok no. 148-171, pp: 1120-1121.
13. Mishra S (2015) Bhaishajya Ratnavali of Kaviraj Govind Das Sen, Edited with 'Siddhiprada' Hindi Commentory, Choukhamba Surbharati Prakashan, Varanasi, Prameha Chikitsa chapter, Shlok no: 102110.

14. Tripathi B (2013) Shadangadhar Samhita, containing Anjannidana of Maharshi Agnivesh, a noted with Dipika hindi commentary Chaukhamba Surbharati Prakashan, Varanasi, Madhyakhanda, Chapter 6/9-11, pp: 117.

15. Wild S, Roglic G, Green A, King H (2004) In the year 2000, 171 million people had diabetes, and this is expected to double by 2030 , Global prevalence of diabetes estimates for the year 2000 and projections for 2030. Diabetes care 27(3): 1047-1053. 